\section{窵 敎}

業 室
窒炬

第 2編：セメントを焼く窯 (4)

\section{吉 井 豊 藤 丸 \\ （秩父セメント株式会社）}

\section{III. ロータリーキルンのタイプと焼成能力}

\section{(1) 墨の長さと径との関係}

Ransom が $\phi 5^{\prime} \times 25^{\prime}$ のロータリーキルンに成功し たことは，既にのべたが，その後羔は次第に長大とな って来た。今これを日米の過去のデータにしたがっ て，歴史的に検討して見ると次のよ5になる。

第 4 表 ロータリーキルンの径 $(\phi)$ と長さ 備 (L) との関係

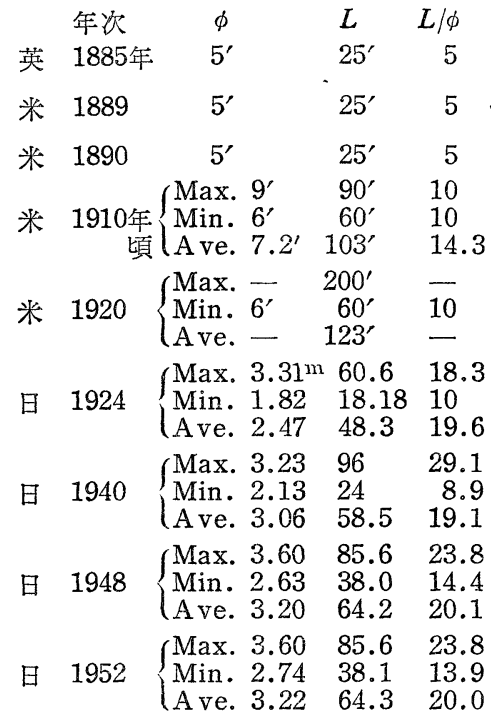

最近の情報によると，目下スエーデンの Limhamn に湿式で $3.6 \times 3.3 \times 3.6 \times 166 \mathrm{~m}$ の突 (F.L. Smidth 社製）を建設中ときくが，これは狺とらく現在に挌け る世界最長の葖で，墨の長さす既に最高限度に来てい るのではないかと考觉られる。

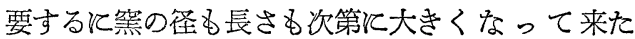
が，長さの方はまさに Ransom の発明した䈍の 21.8

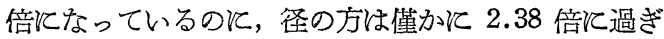
ないが，これは構造上その他の関係で，径は $4 \mathrm{~m}$ が最 高限度と考えられる。その理由は碯の構造上径が大き くなるとセルが弱くなって変形を起し易いことと， 径が余りに大きくなるとセルの厚さを部分的には $75 \mathrm{~mm}$ ，その他の部分も 19 45 mm 位にしなければ ならない上次のような不利が伴う。

a）筀の径の増大に応じてフレーム (flame) の径を 増すことは困難で, 筌の径の増大につれて燒成帯
に预ける伝熱效率は次第に低下する。

b）ロータリーキルンは熱効率のわるい機械である から，なるべく熱ガスを等内長く停滞させる方 が有利であるから, 葖の容積を増すには径を大き くするよりも長さを延ばす方が有利である。

c）わが国でも電源が次第開発され，また余熱利 用によらず別個に発電することが却って有利な場 合も生じて来たから，余熱ボイ ラ一設置の意義が少くなり，た め䄕を長くする傾向を助長し た。

d）今日セメント工場を新設する には莫大の資金一一嘿 1 基月産 15,000t の工場を一つ造るには 少くとも 10 億円はかかる— かかかるら，その建設資金をセ ーブしてなしくずし的に行く意 味で，余熱発電設備を予想しな い長い窐を造るととが有利にな って来たこと。

e）大きな墨でも小さな窯でも所 詮焼手を 1 人つけるとすれば， 大きな突の方が人件費が割安に 上る。

f）保健衛生，風致等の社会問題からダストをなる ベく飛ばさないために湿式のロングキルンが用い られるようとなった傾向認められる。

らなみに，ダストは乾式の短いキルンでは焼出量の 15\%にる括よぶものがあるが, 新しい湿式のロングキ ルンでは普通 $1 \%$ 程度, スミス社の技師の言によれば, 「コットレル収麇機の廃ガスを, 羔の欣込と二次空気 に回収するVan Tongeven のパテントを使用すれば， 日産 $500 \mathrm{t}$ の窯で飛散ダストは僅かに 1 日 24 時間で $50 \sim 100 \mathrm{~kg}$ そ過ぎない」とのことである。これなら ば焼出量の $0.2 \%$ 以下であるから，まずダストはぜん ぜん飛ばないといっても過言ではない。

しかし，割は湿式では長さが最大 $160 \mathrm{~m}$, 径が $4 \mathrm{~m}$ 止りが限度であろ5。もし，乾式ならば乾燥圈だけ短 くならから，和そらくこれより $30 \mathrm{~m}$ 位短いのが限度

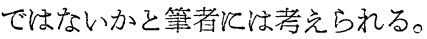




\section{（2）ロータリーキルンの焼成能力}

害の焼成能力は, 焼かれる原料の物理的・化学的性 質, 原料調合物の H.M., S.M. 招よび I.M. そその 粉末度等によって大きく影響されるが，何といっても 本質的とは筀のサイズとタイプに支配される。

筆者はかつてセメント聯合会の工場能力調査委員の 一員として, 内地はもちろん, 満鮮各地の工場も親し く視察し, 当時の乾式キルン 43 基と湿式キルン 5 基に ついて，長期とわたる焼成能力を検討した結果次のよ らな結論を得た。これは今日でもなんら変りはない。

a) セメントロータリーキルンの既存焼成能力公式 の検討

従来セメント回転謇の焼成能力に関する公式として 知られたものは次の通りである。

Meade の公式; $C_{c l}=0.17 A(3 / 4 L+15)$

$$
C^{\prime}{ }_{d l}=\left(0.03246 L^{\prime}+0.1967\right) \pi r^{\prime 2}
$$

Eckel の公式； $C_{c l}=D^{2} \times L / 8 \sim D_{2} \times L / 12$

$$
C^{\prime}{ }_{b}=0.03182 D^{\prime 2} L^{\prime} \sim 0.02121 D^{\prime 2} L^{\prime}
$$

Zollikofer の公式; $C_{c}=0.7$ (up to 0.95 ) $p^{1.5} \times \sqrt{L}$

$$
C^{\prime}{ }_{c b}=0.54(\text { up to } 0.0733) \pi D^{\prime 1.5} \bigvee \overline{L^{\prime}} \cdots\left(3^{\prime}\right)
$$

米国セメント聯合会の公式； $C_{6 i}=P L / C$

$$
C^{\prime}{ }_{c l}=0.01928 \pi D^{\prime} L^{\prime}
$$

ただし $C_{c^{\prime}}$; 乾式回転篣の焼成能力 (bbls/day)

$p ;$ 回転窯内張煉瓦内周 $(\mathrm{ft})$

$D ; "$ "内径 $(\mathrm{ft})$

$L$; 回転娅の長さ $(\mathrm{ft})$

$A ;$ ＂ 内張煉瓦内法断面積 $\left(\mathrm{ft}^{2}\right)$ $\left(1^{\prime}\right),\left(2^{\prime}\right) \cdots \cdots\left(4^{\prime}\right)$ の式は, 筆者が日本の慣 習飞したがい焼成能力 $C_{c l}(\mathrm{bbls} / \mathrm{day})$ を $C^{\prime}{ }_{d}$ $(\mathrm{t} / \mathrm{hr})$ で現わすため $D, L, A$ をとれ皆れ $D^{\prime}, L^{\prime}, A$ そしてメータ一制渙算したも のである。

上式を見ると，(1) 式は案の焼成能力は，その長さ 飞一定の常数を加えたものの内容積に比例するととを 示し，(2) 式は嘿の焼成能力はその内容積に正比例す ることを示し，(3) 式は焼成能力はとの内周の 1.5 乗 そ長さの平方根との積炕正比例し，も乙䈍の径と長さ との比が一定な場合には，との断面積比例すること を示す。また (4) 式は焼成能力は窝の内壁面積炕比例 するととを示している。

しかるに，上の諸公式はそれぞれ日本のセメントキ ルンに当はめて見ると実際とは非常な咝庭がめり，せ っかくのこれらの諸公式るなんら用をなさず，一種の 無用の長物にすぎないのは遺感である。

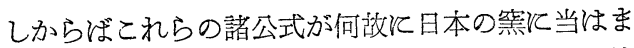
らないかというと，総じて日本の䈍は欧米のそれと比 乙て高能率を発掩しているためでもあるが，主なる原 因はどの式る理論的根抛が薄弱であるか，さもなけれ
ば取材が古くその範囲が狭いためと考兄られる。すな わち，乙の四つの式中 (2),(3) 拉よび (7) は理論的 そ考察したつもりらしいが,筆者侅わせれば,理論を 織りまぜて想像を遈しくしたていう程度にすぎない。 ただ (1)の Meade の式は害験的に求めたるのらし く，他の 3 公式よりは優るが，取材が古くかつその範 囲が狭いため日本の甯に当はまらない。

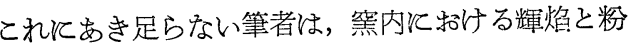
炭䴓の軦射 ${ }^{11}$ ，不輝焰の軦射 ${ }^{2}$ ，管内強制対流 ${ }^{3}$ の場合 の管壁への伝熱等を徹底的に検討して次のよ5な関係 発見した

（3）弿內消費熱量から見た回転竿の焼成能力之內 容皘との関係

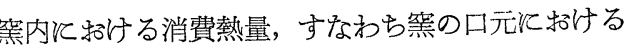
(1) ガスと微微炭の保有する総熱量と，宫尻に 挌ける廃ガス中の包含熱量とセルから逃げ る熱の和との差と, 燒成能力との関係は次 式であらわすととができる。

$$
C^{\prime} \operatorname{cs}\left(T_{1}, V_{g_{1}}, C_{1}-R-T_{2}, V_{g_{2}}, C_{2}\right)
$$

但し $C$; 単位時間内に和ける案の焼出量 $T_{1}, T_{2} ;$ それぞれ塞の口元と䉑尻に 和ける想定ガス平均温度

$V_{g_{1}}, V_{g_{2}} ;$ それぞれ筀の口元と窵尻を単位時間 内に通るガス量 $C_{1}, C_{2} ;$ それぞれ窯の口元と弿尻ガスの平均比 熱

$R$; 単位時間内飞嘿のセルから放散される熱量 な扮石炭は弿入口で一時に完全飞燃えたるの そ仮定する。

上式中 $R$ ほ比輘的小さな值で，大体箩内を通過する 熱量飞比例するるのと考光て差支党ない。今，与兄ら

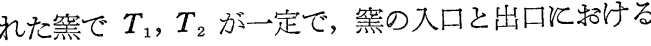
ガス成分が一定である場合は $V_{g_{1}}, V_{g_{2}}, C_{1}$ 抒よび $C_{2}$ は一定となる。

故と今 $R=m T_{1} V_{g_{1}} C_{1} \frac{T_{2} V_{g_{2}} C_{2}}{T_{1} V_{g_{1}} C_{1}}=n$ と置けげ, 上 式は次のようとなる。

$$
\begin{aligned}
& C^{\prime} \backsim\left(T_{1} V_{g_{1}} C_{1}-m T_{1} V_{g_{1}} C_{1}-n T_{1} V_{g_{1}} C_{1}\right) \\
& C^{\prime} \backsim T_{1} V_{g_{1}} C_{1}(1-m-n)
\end{aligned}
$$

しかるに䈘のドラフトを一定とすれば， $T_{1} C_{1} V_{g_{1}}=$ $k V(V$ 㮫の内容積) となるから

$C^{\prime} \cos k V(1-m-n) \cdots \cdots$ となる。

しかると筌のサイズが変化してもkを一定に保てぼ $m$ と $n$ 空のサイズに応じて変り，なかんずく $n$ は 実測の結果現在の回転窝では, 第の内容積の増大につ れて僅かづつ増大する傾向にある。故に竿の焼成能力

1）,2，3） は筆者著 セメント回転䈇の焼成能力飞 就て, 工化, 41 P.653-57 (1938) 参照。 
$\boldsymbol{C}^{\prime}$ は常に内容積 $V$ 亿比例しないが， $V$ の函数である と考学られるから

$$
C^{\prime}=f(V) \cdots \cdots \text { の関係が成立する。 }
$$

以上の根抛から，筆者はまず日本の乾式回転等の焼 成実績によって筀の内容積と焼成能力, 蔒の内壁表面 積と焼成能力との関係をプロットして見た結果, 両方 共ほぼ平滑な曲線を得たが，前者の方がよりスムース な曲線となり，かつは日本の習漬としたがって窯の内 容積と焼成能力との関係飞ついて実験式を求めた。

\section{（4）弿の內容皘亡焼成能力之の関係を示す新公式 の提唱}

わが国では，キルンの容積は一般とシェル内側の容 積をもって測定されているが，これは便宜上で，クリ ンカーの焼出量飞直結するるのは内張煉瓦内側の容積 であるからここではこれを用いることとした。

今, わが国飞和ける昭和 $7 \sim 8$ 年の墨の比焼成能力 とその内容積との関係を求めれば次の通りである。た だし取材の 43 基の案をサイズに応じて内容積 100〜 $200 \mathrm{~m}^{3}, 20 \curvearrowright \sim 300 \mathrm{~m}^{3}, 300 \sim 400 \mathrm{~m}^{3}, 400 \sim 500 \mathrm{~m}^{3}, 50^{0}$ $\sim 600 \mathrm{~m}^{3}$ の 5 群炕分けて各颜のそれぞれ平均值を求 め,これから次の実験式を求めた。

乾式案の焼成能力実験式

$C^{\prime}{ }_{c}=k V C^{\prime}{ }_{d s}=0.04552 k V_{e}(-0.00045 \mathrm{r})(\mathrm{t} / \mathrm{hr})$

湿式嘿の焼成能力実験式

$C^{\prime}{ }_{w}=0.04552 \times 0.75 \times V_{e}(-0.00045 \mathrm{r})$

ただし，この場合の平均運転条件は次の通り。

H.M. = 2.16 S.M. = 2.54(いずれるセメントで) 原料細度； $6.9 \% / 4900$ 孔 微粉炭細度； $13.7 \% 1$ 4900 孔 所要熱量； $2492 \mathrm{cal} / \mathrm{kg}$ (セメント) 湿 式のスラリー水分 $35 \%$

第 5 表 各種様式キルンの比焼成能力係数

\begin{tabular}{|c|c|c|c|}
\hline 式： & $\begin{array}{l}\text { 比燒成能 } \\
\text { 力係数 }\end{array}$ & $\begin{array}{l}\text { (k) 取材 } \\
\text { 弿 数 }\end{array}$ & 取材年次 \\
\hline 乾式（原石法） & 1.00 & 43 & $1933 \sim 34$ \\
\hline " & 1.07 & 43 & 1937 \\
\hline " （石灰法） & 2.09 & 4 & " \\
\hline レポール式 & 1.07 & 2 & " \\
\hline 湿式（カルシネーター） & 0.96 & 4 & $"$ \\
\hline " (フィルター) & 0.99 & 9 & " \\
\hline “（スラリーその出ま） & ) 0.75 & 5 & $1933 \sim 3$ \\
\hline
\end{tabular}

次飞比較のため, 前揭四つの焼成能力公式と筆者の 提唱する公式とによって，䇺の焼成能力と比焼成能力 をそれぞれ計算すれば第 12 図のようである。ただ 乙, 本計算では仮に嘿の内張煉瓦内法を $2.7 \mathrm{~m}$ とし, Eckel や Zollikofer の式を適用する場合には最大最 小限の平均值を用いた。これとよって見れば，日本の セメントはただにとの品質で優秀なるのみならず筧の 焼成能力でも他の追随を許さないととが筧われる。

（5）大形回転弿存在の意義

以上で大形キルンの比焼成能力の少いととがわかっ

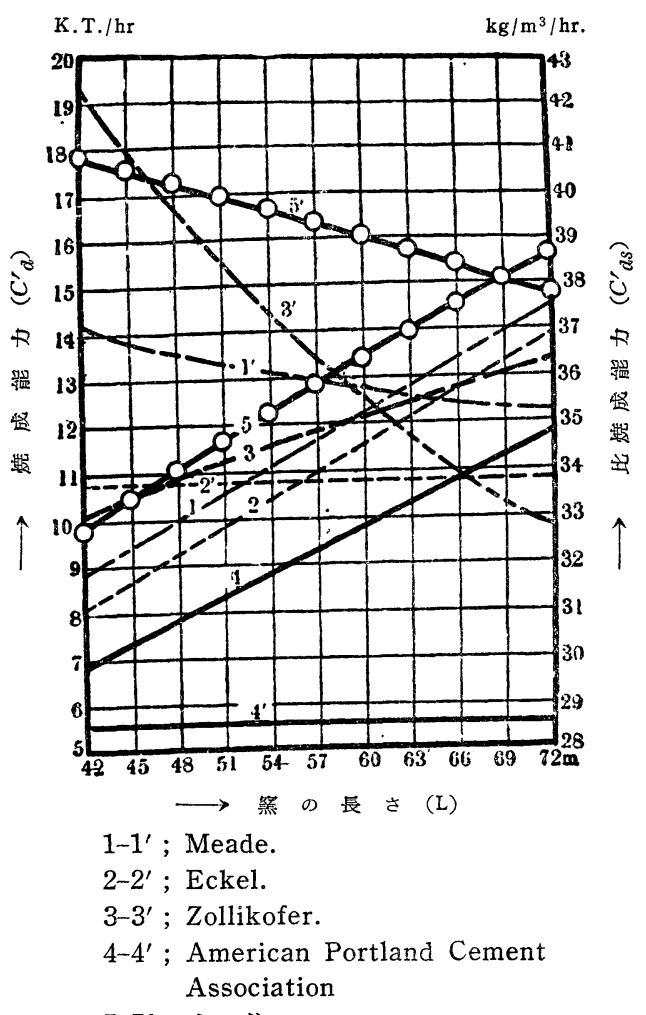

$5-5^{\prime}$; 吉 井

第 11 図乾式回転空恶の焼成能力公式の比較

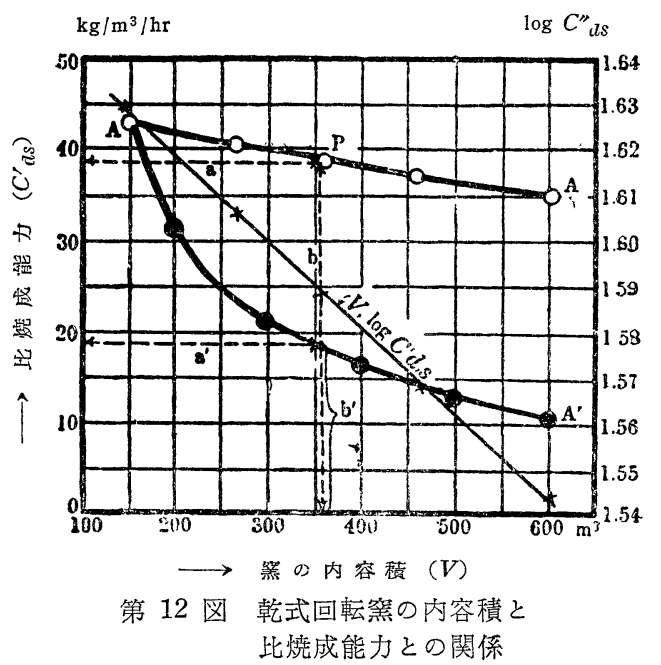

たが，乙からばこれは何と基因するかははなはだ興味 ある問題であるが，これは後日に譲るとして，墨を大 きくして子空の焼成能力は果して増さないかの疑問が 当然起る。

第 12 図で曲線 A-A はわが国の乾式キルンの内容 積とその比焼成能力との関係を示するのであるが，䌜 の焼成能力は丁度この曲線上の任意の点からそれぞれ 縱軸と横軸までの距離の積 $a b$ であらわされるよ5飞 なっている。次に A-A'はこの線上の任意の点からそ 
れぞれ縦軸と横軸までの距離 $a^{\prime} b^{\prime}$ が常に一定になる よ5に選んだ曲線である。故筀の焼成能力は内容積 の増加につれ $a\left(b-b^{\prime}\right)$ づつ増加することになるか ら, 少くとも本研究取材範囲内の䉑では, 焼成能力は 内容積の増大応じて増加する。

しかし，式一12を仮飞補外して $C^{\prime}{ }_{c \text { max }}$ 亿応ずる $V$ を求めれば,次のよ5になり, 乾式キルンでは $V=$ $2.222 \mathrm{~m}^{3}$ が極限值で, これ以上では案の容積を増せば 却って焼成能力の減るととを意味する。

$$
\begin{aligned}
& \frac{\partial C_{c l}^{\prime}}{\partial V}=0.04552 e^{(-0.00045 V)}-0.04552 V \times 0.00045 e^{(-0.00345 \mathrm{~V})} \\
& =0=0.04552 e^{(-0.00045 \mathrm{~V})}[1-0.00045 \mathrm{~V}]=0 \\
& \therefore 1-0.00045 V=0 \quad V=\frac{1}{0.00045}=2222\left(\mathrm{~m}^{3}\right) \\
& C^{\prime}{ }^{\prime} \max =37.212 \mathrm{t} / \mathrm{hr}
\end{aligned}
$$

故に焼成能力に関する限り大形の墨は割が悪いが， 建設費や運転費等では割安になるから，この一事のみ で大形の䇪が不利益なりとは断ぜられないが，セメン トキルンの比燒成能力は㚠のサイズの増大につれて

(1)

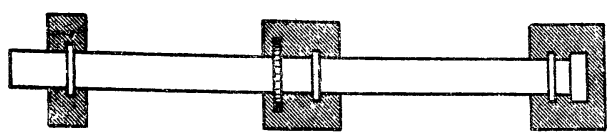

(2)

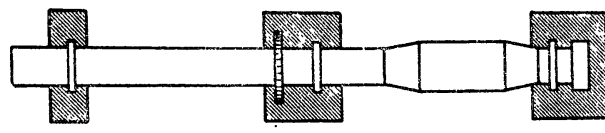

(3)

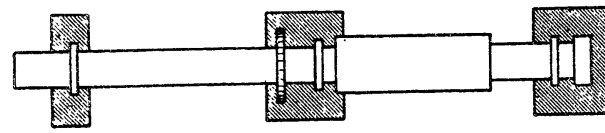

(4)

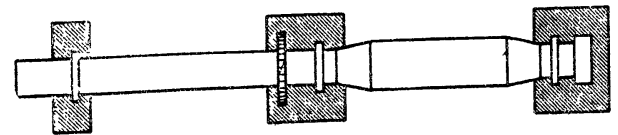

(5)

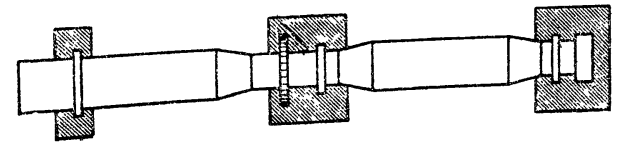

(1) 南円简形の元祖の形

(2) 焼成带を拡大した形

（3）煆焼带から焼成带にかけて拡大した形

（4）焼成带亡椵焼带を抎大した形

（5）煆焼さ焼成带の外乾燥および予熱圈を拡大した形

第 13 図ロータリーキルンの種類

ロータリーキルンは焼成炉であると同時にコンベヤ 一である点が面白い。あれだけの高熱のるのをそのま まコンベャーで運ぶとしたら大変なととで，抗とらく 不可能であろう。

さて, 鮟内に和ける原料の熱処理は場所によって一 样でない。すなわち, 最初は吸熱反応で焼成帯では却

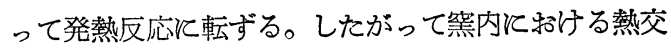
換, 熱処理, したがって原料の受ける熱経歴は終始一 様でない。そこに篅の内径を場所によって変えて，原
派減することだけは明らかである。

\section{（6） ロータリーキルンのタイプ}

回転宗のタイプとは種々あるが，ここではひとまず レポールキルンを除き，一般のロータリーキルンとつ いてのベる。

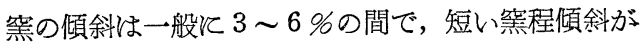
緩やかで, 回転数も少いのが常である。これ反反して 長い割は急傾斜てして早迴しをしても，原料の䉥内停 滞時間がながいから差支えないのみならず，熱交換が よくなる。最近セメントの大量生産飞伴い, ま た熱管理の問題がやかましくなるとつれて長い 割が使用されるようとなって来た理由の一つは ここと岕る。

しかし，みだり箽を長くするとドラフトは

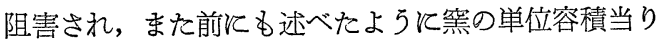
の焼出量が莪減するから，そこには招のずから限度が ある。次汇筭のタイプを図示する。

(1)
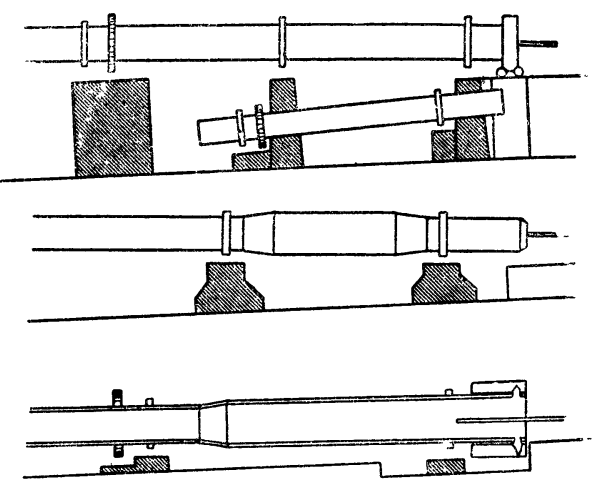

(4)

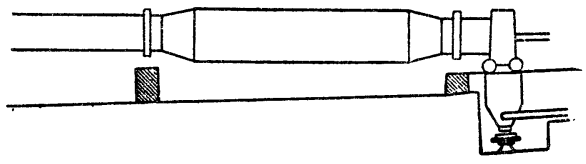

（1）クーラーを別佪にしたアンダークーラー形

(2) 燒成带の手前をクーラーレしたゾロータイプ

(3) レフレックス式多筒式クーラー形

(4) 堅形のクーラー

第 14 困 クーラーの種類

料やガスのスピードを変えたり，伝熱をよくするため そスクリーンをつけたり, チェーンを張ったり,ダム を造ったりする理由がある。

第 13 図の (1) は普通の直円筒形で, Ransom の 最初の篝と同タイプのもので, ロータリーキルンの元: 祖ともいらべきタイプである。

第 13 図の (2) は Pollisius そ F.L. Smidth タ イプのシンターリングゾーンを特に太くしたものであ る。これは焼成帯が高温でガス容積が大きいから，ド 
ラフト関係からす太くするという一応の理由はないて もないが，一方焼成帯では発熱反応が行われることか ら考觉ると，ここを太くする理由は薄弱であるが，実

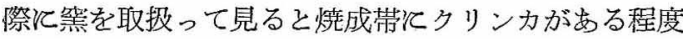
たまっていると熱がこもって燃料つ着火がよくなり， また焙不足のものはむらされ，クリンカー全体がアニ 一ルされるなど有效でめると筆者悢信ずる。

第 13 図の (3) は Fellner Ziegler のタイプで, 大体快（2）《似ているが，多少拡大部が奥へ延びて

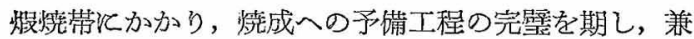
ねて熱吸収の多い层焼带が太くなっている点億義が あると考えられる。

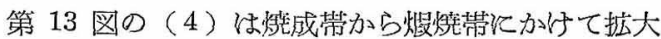
した新しいタイプで，（2）と（3）との合垪的効果 を狙ったるのである。

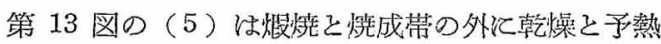
圈の低温圈を应大し，伝熱をよくして，焼成工程への 予備操作の完堭を期するもので，熱效率上扔よび烧出 量の増加対して有效と考光られる。

次に，クリンカーは冷却の如何によって著しくセメ ントの品質に影響さるから，冷规工程は䅉成の仕上工 程そもいらべく，その意味で非常仼重要である。きた

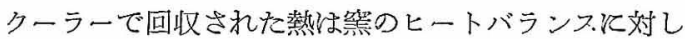
て大きな役割をもつが，こ礼は後のヒートバランスの 項で述べる予定で岕る。

第 14 図の（1）は最も古い轧のクーラーではめる が，墨炕直結したるのと較べると無理がないから，哭 飞累を特よ济すことは少ない。しかし，逆炕クーラー の故障とよって䈉を余䕙なくとめねばならぬとともあ

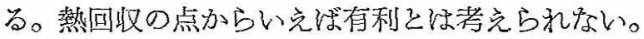

第 14 図の（2）は，いわゆるポリジュース社のゾ ロキルンで，烧成带の末端がクーラーとなっているか ら，クーラー単独の故障とい5もつもなく，末た構造 上無理もないが，乬の代りクリンカーの冷却は不十分 の懢みがある。

第 14 図の（3）は，小さな多筒式クーラーを筧つ 周囲汇つけたもので，熱損失は少いようであるがクリ ンカーが十分さめず，かつ墨炕無理仅取付ているた めクーラーの故障が多く，そのため䇮をとめる機会が かなり多い。このタイプKスミス社つユナックスクー ラーがある（ただしクりンカーの流れる方向はレフレ ックス型と反対)。これも故障は大変多いが，内部化 チェーンを張っているためにクリンカーの冷却效果は 大変によいようである。

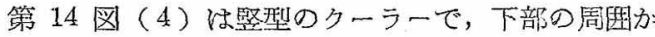
ら压㧒空気を吸込えで冷却する式である。等者もこつ 種のマンステッドクーラーというのを使朋した経駼が あるが，クーラーの真ン中代けがクリンカーの通路と なり，そのため滇赤のクリンカーが出て䦐口したと とがあり，感心しない。

この外花グレートクーラーと称して㥶のクリンカー 出口の下K広いグレートをつけ，これを在とんぞ完全 に团い，圧摧空気をグレートの下から吸込えで冷却す る方法がある。この方法ね，今日のエヤクエンチング クーラ一の元祖ともいうべきもので，熱司収は良好な ようと感じられた。

最後に最新式のエヤクエンチングクーラーの図を紹

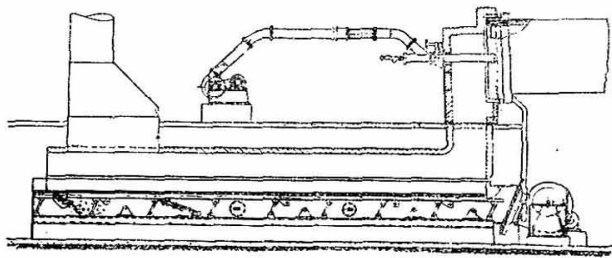

第 15 図アリスチャーマーエヤクエンチン グクーラーの側面四

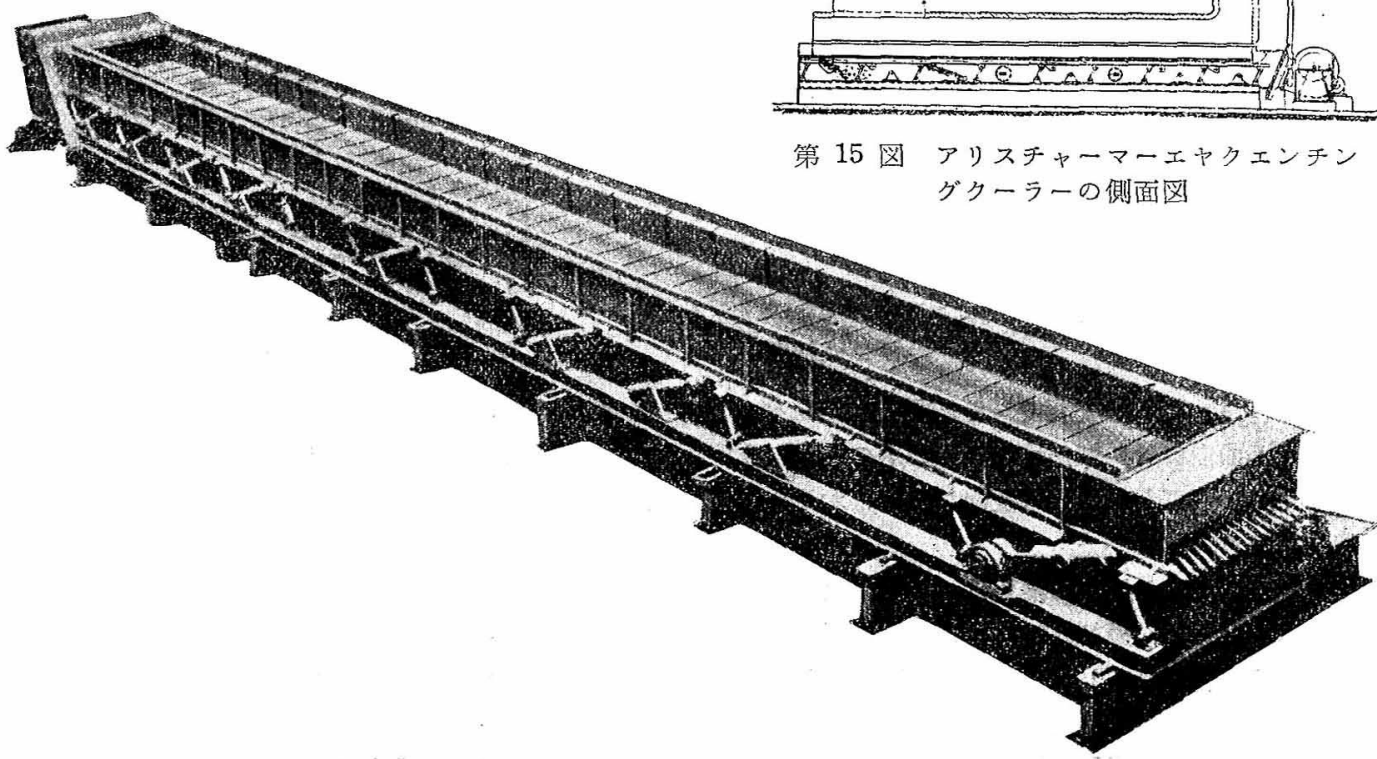

第 16 図 アリスチャーマークーラーのトラフ 
介する。これは長いグレートの上を徐々移動するク

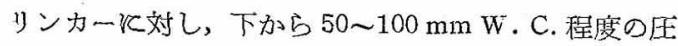
摧空気を吹込んで冷却するすので，ターラー出口のク リンカーは和挌むね手で探られる位であるから，クリ

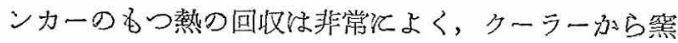
飞入る二次空気の温度は $800^{\circ} \mathrm{C}$ 汇も達するから全く隔 世感があり，正汇近来のヒットというべきであうう。

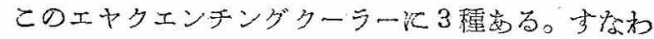
b、フォーラックスクーラー (F.L. Smidth 社), ア リステャーマー式括さびフーラー式の 3 社が現在登争

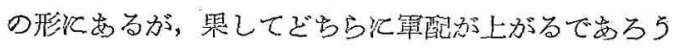
加。

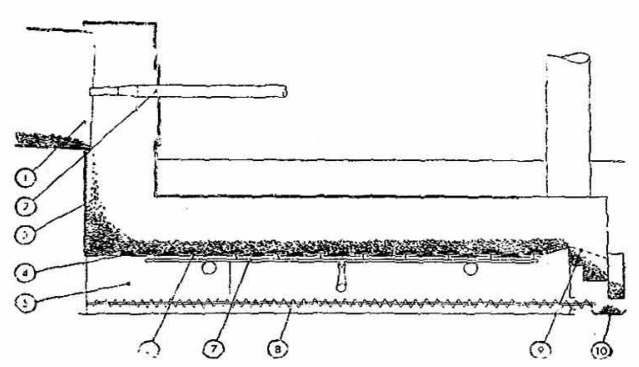
(1) ロータリーキルン地口
(6) コンバヤーパット
(2) バーナーパイプ
(7) 邁淙機稳
(3) 自熹クリンカ1
(1) グレート
(5) 空気荥
(8) スクルーコンパヤ
(3) 口ストル
(10) クリンカコンベ

第 17 図 フォーラックスクーラー

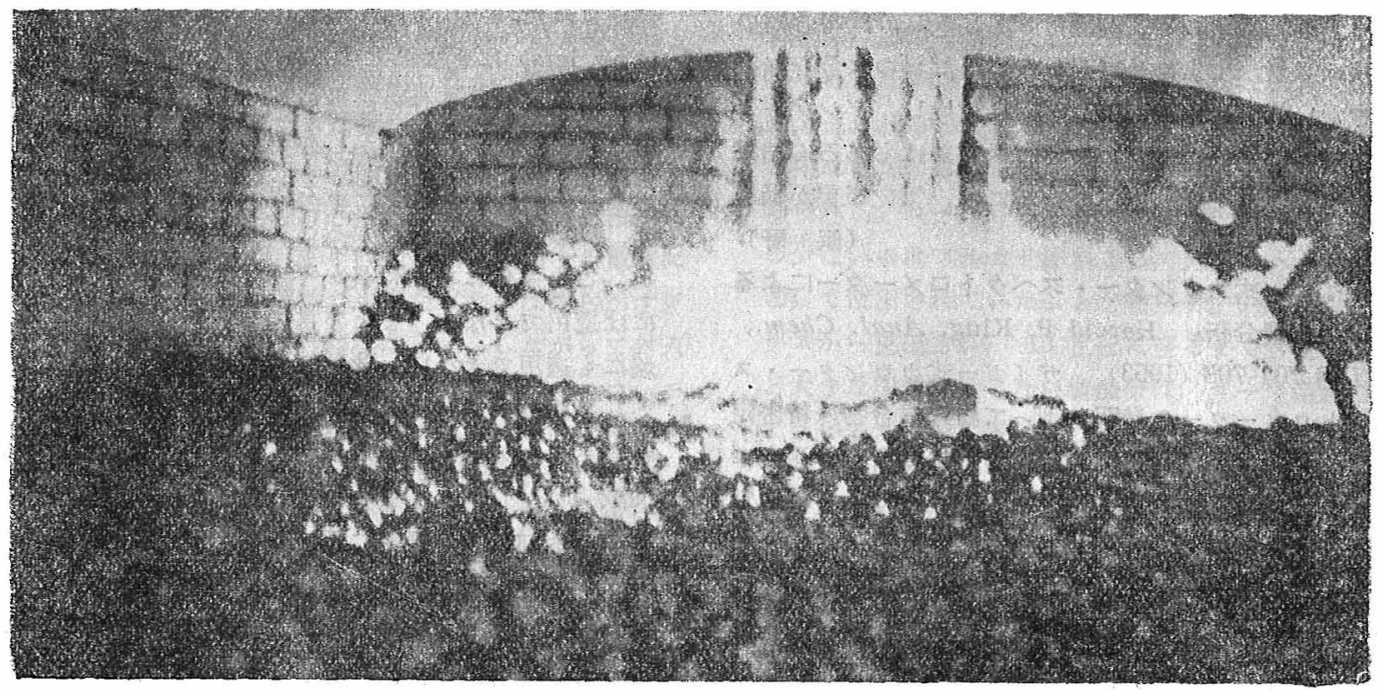

第 18 図 クーラー大ロにタリンカーが落下レている有様（半月形の白い部分は浾熱せるクリン カーが压㩁空気で冷却されている状態）

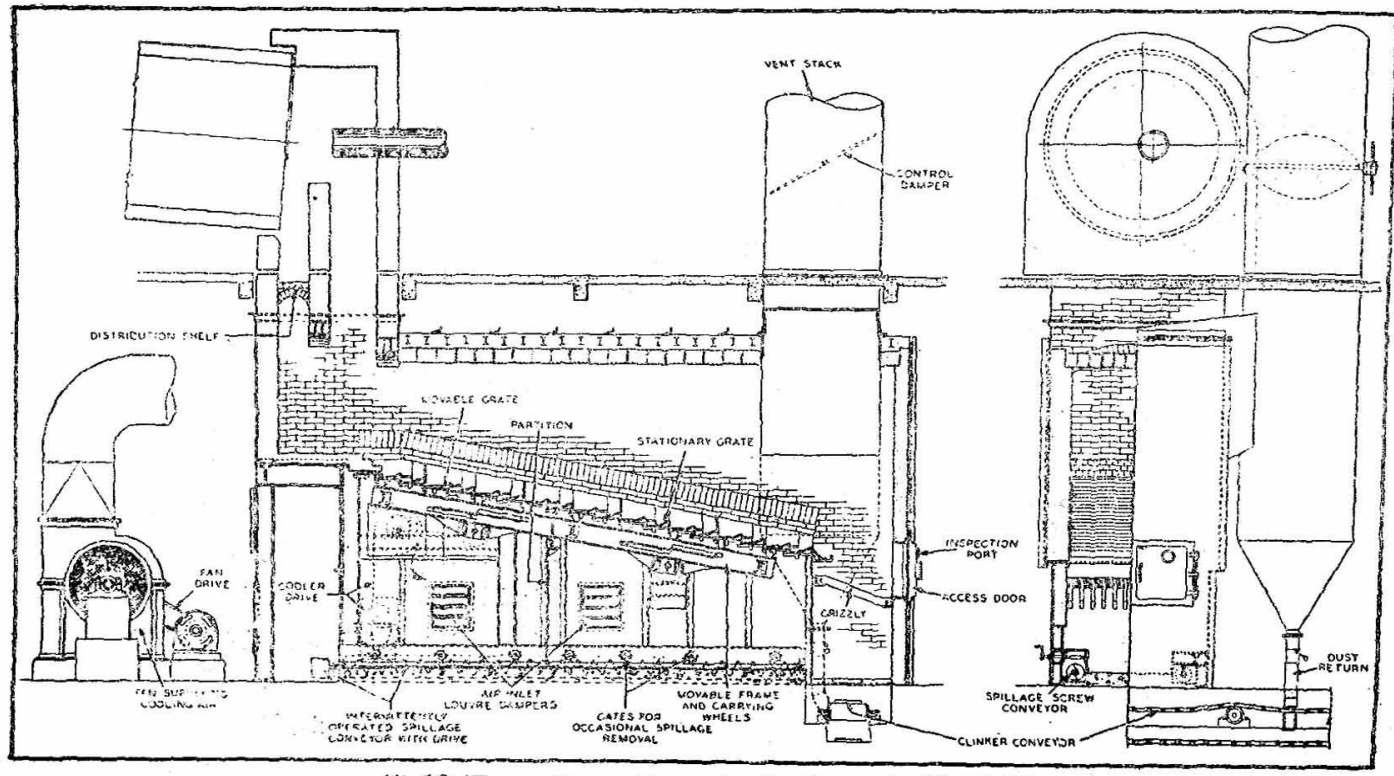

第 19 図

フーシータリラーの側面図 